\title{
Belonging on the Borders
}

\author{
Inez Baranay \\ Independent scholar and novelist \\ inezbaranay@gmail.com
}

\begin{abstract}
Copyright $\subseteq 2017$ Inez Baranay. This text may be archived and redistributed both in electronic form and in hard copy, provided that the author and journal are properly cited and no fee is charged, in accordance with our Creative Common Licence.
\end{abstract}

\begin{abstract}
A personal essay by a novelist in response to the theme of borders and belongings, which sparks thoughts about what belonging is, a life-long sense of outsiderness and its gifts, the pernicious appeal of national identity, and the useful and valuable notion of Transcultural, where non-belongers can belong.
\end{abstract}

Keywords: borders, belonging, nationalism, transcultural

\section{The word belonging starts to sound odd}

The name of the conference is "Borders and Belonging". Its name seems to be enough for me to think, and for someone to say "that sounds like one for you".

As I begin to think about what can usefully or interestingly be said about this topic, the "borders of belonging", the word belonging starts to sound odd, the way familiar words suddenly do sometimes, and a line from a cheesy old pop song of my childhood years comes into my head and stays a while as ear worm, going "I belong to you dear and you belong to me" ...

That kind of belonging, the kind sappy, catchy songs were about, still are some of them, suggests the romantic, the illusory and fleeting. And exclusionary. If you and I belong to each other we don't belong to anyone else and no-one else belongs to us. It's an expression of a weird ideal or a hope and cannot be taken literally without an uneasy rubbing up against the notion of actual slavery, even while voluntary slavery might be the 
ultimate paradoxical freedom in a state of freedom.

Of course, another part of me will respond, we all necessarily exclude what we don't include and none of us can include everything.

Also, I suspect that a longing for belonging is inescapable and that's why it's such a potent subject, whether one is looking for ways to belong or ways to escape it.

Still, what I see is a burden of romantic yearning that attaches to the notion of belonging.

I have tended to refuse to belong to that kind of belonging and I don't know which came first, a realisation or insight about that, or, on the other hand, a credo, a politics.

I'm pretty sure that to the extent there is anything essential and immutable in my self it is in this kind of feeling.

If so, as a novelist, I mine these and allied feelings - outsiderness, demurral about exclusionary relationship - and give a voice to these feelings and explore such themes, through the characters I write.

\section{Faithlessness - in my first novel}

I read a lot of Graham Greene during the early stages of writing my first novel Between Careers (published in 1989, seven years after its completion) and was inspired by him for some sentiments I gave to my narrating character who claims in the last pages, in a mood of a kind of resolution or entering a new transition, that she has discovered that her first allegiance is to "faithlessness".

This was written about 35 years ago and it expressed something the writer strove to articulate, a kind of credo:

It must be addictive, this feeling of being essentially rather faithless. Without creed, allegiance, attachment. [...] Well, without the obvious attachmentsreligious, political, romantic. But what she'd just called faithlessness required the most binding commitment. Which was a kind of attachment.

[...] What she'd just called faithlessness was the choice she felt chosen by. It was a choice of an extended world of possibilities. It included opposites and contradictions and outlandish conjunctions. It meant that even the most witless and tedious moments in another breath could turn everything hopeful and enthralling. And not stop there. (Baranay 1989)

I must have liked the idea at the time.

I don't dislike it now. 


\section{Betrayal}

And it is Greene again who reminds us that belonging brings with it the possibility of betrayal, and therefore gives rise to arguments about what is the greatest betrayal. Speaking of the British Spy Kim Philby Greene says, "'He betrayed his country'-yes, perhaps he did, but who among us has not committed treason to something or someone more important than a country" (Osborne).

Which of course brings to mind EM Forster's declaration that he would rather betray his country than his friends. This makes us ask questions like: Do you belong to your country above all belongings? And what is your country?

And so we come to that vexed notion of nationality.

The recent death of Benedict Anderson reminded us of his valuable concept of imagined communities and discussing that could hijack the rest of what I might say here but I'll mention two things apropos: 1: that the concept of nations has fulfilled in a religious way the idea of belonging and 2: that there seems something central to human experience to feel a connection with other people most of whom one will never meet but are in some sense of one's own kind however that might be understood. And it's often understood in terms of a shared nationality.

And another thing: that there is no border until it is imagined and others also believe it is there.

\section{Torres Strait: borderlines, maps}

I think of the time I lived in the Torres Strait Islands, that sea strait between the Australian mainland and Papua New Guinea; the Strait's Indigenous people are the same Melanesians who populate the southern areas of PNG, and family and trading connections have always united the whole area. One day, there was a line drawn on a map, a line through the Torres Strait, making some people residents of one country, Australia, and some of the other, Papua New Guinea, even while for aeons they had had no notion of any such line, and even while they continued to visit and trade with each other, with official permission up to a point, thus bestowing fresh, odd (and even absurd) challenges to the work of border patrol, the official government border control, who had to tell from their surveillance flights which bits of going back and forth they saw were legal and which were not.

There are so many stories from areas whose official borders are redrawn and where people might wake up one morning to find that they are living in a new country even while they have not moved. There was a joke in Eastern Europe about someone who had lived in seven different countries without ever leaving home. 
The population exchange of Greece and Turkey in 1922

I live on another sea strait now, the Dardanelles, where the ships of the Odyssey fleet once sailed past, and Troy is a short distance down the coast, but now who thinks of Turkey as the ground of Hellenic culture?

In Turkey, now my country of residence, an absurd and ill-conceived population exchange took place when in 1922 between Greece and Turkey a line was drawn with particular emphasis and intent and people who had spoken Greek in Turkey and Turkish in Greece, living in a mélange of cultures that to me is the very essence of civilisation, were made to move to their side of this newly emphasised border with a newly emphasised, even newly creative, newly exclusive distinctiveness to their identity, its primary component a new sense of nationality.

\section{Making meaning / nationality}

We humans are the meaning-making animal. We look for causes, sources, origins, influences. We ask why and how. We cannot accept living in a universe entirely random or one in which nothing can be truly known. The likes of us, educated and socialised in a certain way, are influenced by Psychology and a sense of linear time. Therefore I point to my origins as a migrant child in 1950s Australia as a source of an essential sense of outsiderness; that and the addiction to reading, soon followed by an addiction to writing.

Because of this background, I was from an early age alert to the odd use of the word nationality. What nationality was my name, people would ask me; they asked me what nationality I was. Well, I had Hungarian parents but was born in Italy, what did that make me? I found out that officially I had been born unable to claim any nationality; I was in the category "displaced person" at birth.

So that could be a kind of explanation. Or cause. The sense of displacement as essential, unalterable, persistent. A source of distress at worse, of intellectual and creative curiosity and stimulation at best.

\section{The idea of nationality}

The idea of nationality in my view has given rise to some of the most pernicious aspects of human life. In any case, it has always had a weird ring to it in my experience, for what can nationality mean to a migrant child who was always asked about the "nationality" of her name or of her existence?

And now I find it is so common ...

And now I find it is so common that identity is not understood as nationality nearly so 
much, that so many people have a mix of nationalities in their official identities, that it's unexceptional to grow up in a different country than you were born in, live and work in countries you are not a citizen of, become a citizen of more than one nation, be inspired by writers and artists who involved you in cultures you had not previously been part of, and to find affinity in intellectual, artistic productions that dissolve notions of the foreign.

It is common, now, in our connected online world, to understand and discover your people, your tribe, through your common interests, passions, ethics, politics.

What travels show you / trans-national affinities

I spent a lot of time in India, making many trips over 35 years; traveling, researching, writing, giving talks and classes; attending concerts, plays and films. Three of my books were first published there. In India it was made clear to me, as I joined like-minded people in seminars, interviews and informal conversations, and as I formed friendships, both of finite and infinite duration, that I shared cultural references, humour, political sympathies, literary favourites and a range of tastes and values with many people there. It was made clear that affinity is trans-national. We had more in common with each other than with many people of our own nations.

This insight is the bedrock of my current understanding of why normal, unexamined notions of belonging and borders do not reflect real lived experience for some of us. Nationality, even ethnicity, even class are not indicators of anything more than themselves.

"Where do you belong?"

"Where do you belong?" This question was put to me recently at a talk I gave, where I was questioned about the many relocations in my life, the different places I have lived in. I overlooked the begging-the-question aspect, that is, the assuming that everyone does belong somewhere. I treated the question as if it had an answer. I did not know what I was going to say when I answered: I belong to my network of friends, to the web of friendship made by people I love and keep communicating with. I belong to friendship.

\section{Also to cities}

On further reflection, there is more.

My recently published memoir is called Local Time a memoir of cities, friendships and the writing life.

You're "on local time" when you've stopped remarking on or being aware of what time it is somewhere else you've recently departed, when the time zone of your current locality has become the time to which you are now attuned. As seasoned travelers know, the 
sooner you think local time the sooner you overcome jet lag, the sooner you're in tune with your current environment. A border has dissolved between you and where you are.

So besides friendships also I belong to cities. Though I have spent several long periods in very isolated places, and appreciating their particular beauties and pleasures, I return any chance - and hope to return indefinitely - to old inner-city environments, for the particular vitality and intensity of the streets with their historical layers, for their architectures, for the greater possibility of real life conversations and encounters in which that spark of fellow-feeling, of connection can be found.

To quote the narrator of my novel With The Tiger speaking of the Indian city Madras:

Madras was a provincial city compared to the movie, business, fashion and crime glamour of Bombay or the government, education and research centres of Delhi but it had the buzz and energy, the sense of history, diversity, tension, tolerance, industry, initiative and miscegenation that great cities have. (Baranay 2008)

\section{Mostly to writing}

Mostly I belong to writing. Writing has always been compelling, essential-what can be called a vocation, rather than a choice or an option from a range of career possibilities. Why this is so belongs to all that is mysterious about life and existence for just as there is no definite answer to the question why is there something rather than nothing there is no answer to why someone should persist in writing; one might offer reasons out of the mystical or the psychological dimensions but now I accept an absence of reason. To live a life where writing is central takes care of a range of other consequent choices.

Now-What about the logical fallacy in the question about where you belong? Why assume we all do belong somewhere, do we have to, is it a lack if we don't?

\section{Belonging to borders}

When we put the words belonging and borders together at first it's as if borders marked the end of belonging, marked where the belonging stops. But I wonder if in fact some of us belong only on borders. Suddenly I find that a pleasing notion, in keeping with our era's sense of fluidity and indeterminacy in so many aspects of identity that once might have seemed fixed.

Let's live where distinct and exclusionary identities are permeable, labile, constantly evolving.

That's where we belong. To the borders! Let's live on borders. Until all borders, like Hamlet's too too solid flesh should melt thaw and resolve itself into a dew, until then, let's live on borderlines! 
But wait, what happens when a border expands to become a space which might have its own borders? What is it now?

Maybe, then, it becomes a transnational space and a transcultural space.

\section{The necessity of transnational literature}

Dubravaka Ugresic calls transnational literature "a new cultural platform, a literary territory for those writers who refuse to belong to their national literatures, or to belong to their national literatures only". (Medin)

Elsewhere, Ugresic says this:

The construction of a context — of a literary and theoretical platform, a theoretical raft that might accommodate the dislocated and de-territorialized; the translation and a-national; cross-cultural and transcultural writers; cosmopolitans, neo-nomads, and literary vagabonds; those who write in "adopted" languages, in newly -acquired languages, in multiple languages, in mother tongues in non-maternal habitats; all those who have voluntarily undergone the process of dispatriation - much work on the construction of such a context remains.

I think to some extent this transcultural space already exits - we might all inhabit it to some extent; some of us work in it with a growing realisation of what it is and why borders (that are confining categories) create or perpetuate falsity in the categories, or the lack of them, that try to name the positions from which we write.

The space has been described in her invaluable work by Dagnino thus:

transcultural continuum/transpace/transplace. An all-inclusive space of subjective consciousness and cultural possibilities which does not deny the formative importance of native cultures (and, to some extent, their accompanying worldviews) but at the same time allows an openness to the reception, integration, negotiation, and permeation of other cultures, languages, worldview

transpace/transplace. Another way of defining the transcultural continuum. Transpace/transplace is the transcultural dimension that lies beyond the divides, often commercially or ideologically emphasized, of cultures. It represents a nonoppositional point of confluence or overlapping of cultures that in many ways expands Bhabha's notion of the third space, the in-between space where hybridization occurs.

In my experience, we live in transcultural space when we reject, ignore or transcend the divisions and categories of identity that emphasize difference and separation. This is a space in which a range of worldviews co-exist, where many languages are spoken even while English is recognized as our current lingua franca; English is spoken in multiple 
accents, dialects and variations and part of the work of transcultural space is to acknowledge this. As I have recently written, summarising a long consideration:

Everyone in here knows some version of the world language; it's English now and the word has but a historical connection to the people of England; the language is not defined by, not authorised by, the England where it purportedly originated, at first spread by former forms of imperialism. In here, we speak English. Not England language. (Yes, let's use England as the adjective for "from England". As in cricket: "the England team".) (Baranay 2016)

In transcultural space, borders which are lines drawn by men on maps have no bearing on our senses of connection, empathy, community. Final definitions of identity are indefinitely deferred. Foreignness is a kind of nationality. Home is wherever you're sleeping that night. Where you "come from" is where you've just been, or once have been. Writers do not belong to their national literature but to the world of literature. Every difference co-exists.

Transcultural space, then, is where the unbelonging can belong.

As a writer, if I belong anywhere, it is here.

-ends-

This essay is based on a talk given at the conference "Go Between, In Between: Borders of Belonging" held at the Australian Studies Centre at Barcelona University, January 2016. My attendance was made possible by support from the Creative Individuals Career Fund of CAL, Australia.

\section{Works Cited}

Baranay, Inez. Between Careers. Sydney: Collins. 1989

-----. With The Tiger. Delhi: HarperCollins India. 2008

-----. "Transcultural Space and the Writer" Humanities 2016, 5(2), 28; http://www.mdpi.com/2076-0787/5/2/28/html

Dagnino, Arianna. Transcultural Writers and Novels in the Age of Global Mobility. West Lafayette: Purdue UP, 2015, pp. 201-2.

Medin, Daniel. "A Conversation with Dubravka Ugresic" Music and Literature 18 May 2015 http://www.musicandliterature.org/features/2015/5/12/a-conversation-withdubravka-ugresic

Osborne, Lawrence. "Agents of Betrayal: a reconsideration of Graham Greene's Our Man in Havana" Lapham's Quarterly http://www.laphamsquarterly.org/spies/agents-betrayal Ugresic, Dubravaka Europe in Sepia. Edited by David Williams. Translated by 
Rochester. New York: Open Letter, 2014

Inez Baranay was born in Italy of Hungarian parents and grew up in Australia. In the 1980s she began publishing short fiction in small press anthologies of experimental, feminist and multicultural writing. Since 1989, she has published over a dozen books of fiction and non-fiction ( 3 of them first published in India), as well as many short stories and essays. Most recent books are a novel, set in Berlin, Ghosts Like Us, and Local Time: a memoir of cities, friendships and the writing life. She has a $\mathrm{PhD}$ in Creative Writing from Griffith University. In Australia, India, USA and Europe, Inez has lectured on writing issues and taught creative writing in universities, schools and community groups, given many readings and talks, been a guest at conferences, seminars and literature festivals, and been a resident at various international writers' centres. She has lived in Turkey since 2011 and currently teaches literature there. 